\title{
Comparison among Four Method for Diagnosing Rubella Virus in Pregnant Women
}

\author{
Mohammed H. Alwan' ${ }^{1}$ Mohammed A. Saleh², Nadira S. Mohamed ${ }^{3}$ \\ ${ }^{I}$ M.Sc. Biology Department, University of Diyala- College of Education for Pure Science, Iraq, ${ }^{2}$ Ph.D. Prof. \\ Biotechnology Department, University of Diyala-College of Science, Iraq, ${ }^{3}$ Ph.D. Assist. Prof. Forensic DNA for \\ Research and Training Center, Alnahrain University, Iraq
}

\begin{abstract}
This study was intended to determine rubella virus seroprevalence in pregnant women. The samples included 240 women who attended during the duration from October 2018 to May 2020 Al-Batool Gynecology Hospital in Baqubah District. Women's age ranged from 16-45 years; their age mean was 26.38 years. Data including age, number of previous abortions. Sera were collected from each woman, and the levels of rubella IgG and IgM were detected by use Electrochemiluminescence (ECLIA), enzyme-linked immunosorbent assay (ELISA) and On Site Rubella IgG/IgM Rapid (OnSite) tests. Also, RT-PCR test are used to detect rubella viral RNA. The results revealed that anti-rubella IgG antibodies for the 240 pregnant women were ranges from $84.58 \%$ to $89.58 \%$ depending on the method tested used. While the anti-rubella IgM antibodies for the 240 pregnant women were ranges from $5 \%$ to $5.41 \%$ depending on the method tested used. Only 8 from 240 specimens of pregnant women are rubella viral RNA positive with (3.33\%) percentage by RT-PCR test. In relation to the history of abortion, the seropositivity of rubella antibodies were $(61.42 \%)$ of pregnant women had history of abortion with significant relation $\mathrm{P}<0.05$, however the abortion frequency among Pregnant patients have the past of one or more abortions with the nonsignificant $\mathrm{P}>0.05$ relation.
\end{abstract}

Keywords: Rubella, IgG, IgM, ELISA, Electrochemiluminescence.

\section{Introduction}

Rubella is caused by an RNA virus belonging to genus Rubivirus and family Matonaviridae (formerly belonged to Togaviridae ${ }^{[1]}$. Most infections with rubella cause mild, self-limiting measles-like disease, the real danger occurs when the fetus is infected with the rubella virus $^{[2]}$. Before 20 weeks of pregnancy, problems such as miscarriage or birth defects can occur if contaminated by childbearing women ${ }^{[3]}$. As the virus may attack any portion of the growing fetus, any organ may be damaged ${ }^{[4]}$, this number of congenital malformations known as congenital rubella syndrome (CRS) may involve the brain, heart, hearing, and vision. ${ }^{[5]}$. Laboratory studies for CRS include immunoglobulin rubella $\mathrm{M}$ ( $\operatorname{IgM})$ in cord blood or baby serum, immunoglobulin G (IgG), and chain reaction polymerase (PCR). The infection of maternal rubella sometimes goes unnoticed, as there is always no rash ${ }^{[6]}$. Reliable laboratory confirmation of confirmed cases of rubella is a prerequisite to successful control of this disease>s removal process ${ }^{[7]}$. This study was planned to analyze a sample of the awareness of pregnant Iraqi women about the risk of rubella during pregnancy; assessing their attention to pre-conception prevention and knowledge of their serological status, correlated with the miscarriage and rubella congenital syndrome, to verify the likelihood of achieving the elimination of rubella congenital syndrome. Therefore, the goal of that analysis was to determine seroprevalence of the rubella virus; precisely the seropositivity of rubella immunoglobulin G (IgG) and immunoglobulin M (IgM) rates, compared to three laboratory method for rubella IgG and IgM detection. Additionally, molecular viral infection detection through real-time polymerase chain reaction (RT-PCR). Also study the relationship between rubella infection in a sample of pregnant Iraqi women with and without prior history of abortion.

\section{Materials and Method}

The study consisted of 240 pregnant women who suffered from gestational disruption or had a history of previous abortions. The age of pregnant women varied between 16- 45 , age mean of them was 26.38 years. A 
consent form explaining the dimensions of the study was obtained from each woman either as a written form or an oral form. Data including age, number of previous abortions, via a straightforward interview. Samples from these persons were collected only if we had no records of serious or extreme diseases. Blood collection was done using disposable syringes and needles. Each individual had obtained $5 \mathrm{ml}$ of venous blood in the appropriate vein. The blood collected was passed directly into sterile plain gel activator tube then allowed to stand at room temperature for 10 minutes to give the clot activator included in the tube time to react, And then centrifuged at room temperature to remove the serum at $5000 \mathrm{rpm}$ for 10 minutes. The serum was dispensed through three closely packed, Sterile, and polished eppendorf tubes $\left(-20^{\circ} \mathrm{C}\right)$ screened for detection of IgM and IgG against Rubella in serum specimens by using three techniques: the enzyme- linked immunosorbent assay (ELISA) method, (Abnova kit, Spain), Rubella IgG/IgM Rapid on-site (OnSite) (Biotech, Germany) and Electrochemilumiscence (ECLIA) immunoassay method (using Rubella IgG, IgM Cobas Entegra 411 kit (Roche/Germany). Also RTPCR test are used to molecular detect rubella viral RNA by use (RNA extraction kit and Real-time PCR search for qualitative identification of Infectious rubella, both were from Sacace, Italy).

Statistical Analysis: The machine helped in processing results. Statistical research the test was performed using SPSS (Statistical Social Science Package), version 20 of the program. Distribution of frequencies and percentage was done for the element you chose. The standalone t-test was used, and a significant amount of P-Value less than 0.05 was deemed.

\section{Results and Discussion}

Table 1 Results of ECLIA, ELISA, OnSite tests for detection of IgG, IgM and both IgG \& IgM antibodies of Rubella Virus in pregnant women

\begin{tabular}{|l|c|c|c|c|c|c|}
\hline \multirow{2}{*}{ Method } & \multicolumn{2}{|c|}{ Result of IgG } & \multicolumn{2}{c|}{ Result of IgM } & \multicolumn{2}{c|}{ IgG \& IgM } \\
\cline { 2 - 8 } & Positive n(\%) & Negative n(\%) & Positive n(\%) & Negative n(\%) & Positiv n(\%) & Negative n(\%) \\
\hline ECLIA & $210(87.50)$ & $30(12.50)$ & $12(5.00)$ & $228(95.00)$ & $7(2.91)$ & $25(10.41)$ \\
\hline ELISA & $203(84.58)$ & $37(15.41)$ & $12(5.00)$ & $228(95.00)$ & $6(2.50)$ & $31(12.91)$ \\
\hline OnSite & $215(89.58)$ & $25(10.41)$ & $13(5.41)$ & $227(94.58)$ & $8(3.33)$ & $20(8.33)$ \\
\hline
\end{tabular}

Table 2 Result of Real-Time PCR test for the qualitative detection of Rubella Virus

\begin{tabular}{|l|c|c|c|c|c|}
\hline Method & Viral RNA Positive & Percentage \% & Viral RNA Negative & Percentage $\%$ & Total \\
\hline RT-PCR & 8 & $3.33 \%$ & 232 & $96.66 \%$ & 240 \\
\hline
\end{tabular}

Table 3 Relation of Seropositive Rubella IgG Antibodies in Pregnancy with History of Abortion and Abortion Frequency

\begin{tabular}{|c|c|c|c|c|c|c|c|c|}
\hline \multirow{3}{*}{$\begin{array}{l}\text { No. of pregnant women } \\
\text { with anti-rubella IgG } \\
\text { antibodies }\end{array}$} & \multicolumn{8}{|c|}{ History of abortion } \\
\hline & \multicolumn{2}{|c|}{ No abortion } & \multicolumn{2}{|c|}{1 abortion } & \multicolumn{2}{|c|}{2 abortions } & \multicolumn{2}{|c|}{3 abortions or more } \\
\hline & No. & $\%$ & No. & $\%$ & No. & $\%$ & No. & $\%$ \\
\hline \multirow{2}{*}{210} & \multirow{2}{*}{81} & \multirow{2}{*}{38.57} & 69 & 32.85 & 33 & 15.71 & 27 & 12.85 \\
\hline & & & \multicolumn{6}{|c|}{$129(61.42 \%)$} \\
\hline Abortion & \multicolumn{8}{|c|}{$\mathrm{P}=0.034 \mathrm{P}<0.05$ Significant } \\
\hline Abortion Frequency & \multicolumn{8}{|c|}{$\mathrm{P}=0.382 \mathrm{P}>0.0$ Non Significant } \\
\hline
\end{tabular}

The results in a table (1) showed that anti-rubella IgG complete seroprevalence in pregnant women that are obtained in the present study ranged from $84.58 \%$ to $89.58 \%$ depending on the method tested used. This result is almost similar to a previous study conducted in the target population, Diyala province, Iraq, has obtained higher rate $(91 \%)$ of rubella $\operatorname{IgG}^{[8]}$. While the Synchronized study conducted in Zakho City, 
Kurdistan Region, Iraq has obtained a slightly lower rate $(83 \%)^{[9]}$, another study also Synchronized with this study conducted in Baghdad has obtained a higher rate (95\%) for IgG and $(9.8 \%)$ percentage for IgM antibodies ${ }^{[10]}$.

Studies in the other countries had reported variable results. The seropositivity rate of rubella virus in pregnant women of Turkey are recorded $(86.5 \%)$, $(0.5 \%)$ for $\operatorname{IgG}$ and $\operatorname{IgM}$ respectively ${ }^{[11]}$. In Sweden, rubella seropositivity had (89\%) of all female and (93.4 $\%)$ of the male donors tested ${ }^{[12]}$.

Seroprevalence studies offer information on the susceptibility to infection of certain populations, including women of childbearing age ${ }^{[12]}$. Nonetheless, all of these studies refer to the same message: that some women of childbearing age may be susceptible to rubella given that CRS is a serious concern for rubella infection during pregnancy, immunity to rubella is of particular importance in post-young women. Consequently, it advises (i) taking any opportunity to evaluate rubella immunity in women of childbearing age (e.g., consultation with preconceptions), (ii) all pregnant people must be tested for their rubella serostatus, and (iii) prone adults must be vaccinated either preconception or postpartum due to removal from the hospital ${ }^{[13]}$.

In this study only12 (5\%) of cases were positive for IgM antibodies, that's as rubella IgM typically declines the next 2-3 months post-infection [14], this result proposes that women positive for $\operatorname{IgM}$ can have an active infection by the virus. The specimen's women of IgM positive and IgG negative reflects the occurrence of the new seroconversion (a new infection with rubella virus) or reinfection ${ }^{[15]}$. While those who exhibited $\operatorname{IgG}$ positive sera with negative IgM reflects those immunized or previously infected persons, which instituted the majority of the studied populations.

These differences in results among laboratory techniques that are used in this study (ECLIA, ELISA, The rapid onsite) diagnosis method can be attributed to many chief factors such as its variance in the gray zone, cutoff, and the antigens that using in Complete virus assays (or recombinant antigens). In Iraq, many test procedures are used to identify persons whether or not they are contaminated or immunized with the rubella virus. The rapid onsite diagnosis method is used in private laboratories on a large scale and the Electrochemiluminescence method is used in the laboratories of government health centers and the ELISA method is used on a smaller scale.
The development of rapid and perfect laboratory competencies for the identification of pathogens is essential in the application of effective prevention and control strategies against infectious diseases [16]. Although much progress has been made in diagnostic testing such as that for the care of individual patients or the quick detection of pathogens during disease outbreaks, several of these testing modalities need a skillful operation and complex equipment, which has restricted their use for onsite testing ${ }^{[17]}$.

According to the statistics of the Iraqi Ministry of Planning, central statistical organization; the population of Iraq is approximately thirty-nine 39 million in 2019. And by performing a calculation, $48 \%$ of the Iraqi population is female, this means nearly 18.7 million women in the Iraqi population, and $49 \%$ of these women are of childbearing age, which approximately 9.16 million women at childbearing age ${ }^{[18]}$. According to our study, $12.5 \%$ of specimens were negative for rubella IgG antibodies, that is, approximately $1.145,000$ of Iraqi women are of childbearing age and at risk of contracting rubella virus and developing CRS. Taking into consideration that Iraqi women who become 32 years old or older were not immunized against rubella, as MMR schedule was incorporated into the Iraq National Immunization Program in 1988.

The results in a table (2) showed that only 8 from 240 specimens of pregnant women are rubella viral RNA positive with ( $3.33 \%$ ) percentage, while 232 specimens of pregnant women are rubella viral RNA negative with $(96.66 \%)$ percentage. The results in the present study were also consistent with the results of another study, the result has been reported by ${ }^{[19]}$ showed only $6(10.5 \%)$ were positive for Rubella virus by use RT-PCR test from $46(80.7 \%)$ are positive by ELISA test. This negative result is very low concerning the positive result when measuring the samples depending on the presence or absence of rubella IgG and IgM antibodies. Where from 12 or 13 positive IgM results, which represent an acute infection, only 8 of them appeared positive in a way of RT-PCR. This result can be explained on the basis that the positive result with the RT-PCR technique appears only when the RNA of the virus is present in the sample.

A conclusion in a table (3) indicates the association between anti-rubella antibodies and abortion and the number of abortions. The total rate of abortion was $61.42 \%$. The rate of abortion number was $32.85 \%$, $15.71 \%$, and $12.85 \%$ for one, two, and three abortions 
or more respectively. Furthermore, pregnant women that had a history of abortion with significant relation $\mathrm{P}<0.05$, however, the abortion frequency were had no more deferent recorded among pregnant women with a history of one abortion or more with non-significant relation $\mathrm{P}>0.05$. The current study showed a significant relationship between the history of miscarriage and the presence of rubella antibodies (as shown in Table 3), $61.58 \%$ from the total seropositive pregnant women had a history of abortion. The miscarriage may be due to the effect of rubella on systemic and local (placenta) immunological response. There was non-significant relation $(\mathrm{P}>0.05)$ between the presence of rubella antibodies and the number of abortions, this finding may reveal the ability of the rubella virus to cause miscarriage only one time. This finding is consistent with the findings of most other studies that found a history of miscarriage and is significantly associated with rubella seropositivity ${ }^{[20,21]}$.

\section{Conclusion}

Most women are seropositivity of rubella IgG. Rubella virus is presented as an etiologic factor for spontaneous abortion in this area of Iraq; therefore routine screening rubella is needed for pregnant women. This study limitation, future study including children and adolescents of various ages would allow the knowledgeable susceptible women and determine the outcome of the pregnancy and hazardousness of CRS in our province. The differences in results among laboratory techniques that are used in this study (ECLIA, ELISA, The rapid onsite) diagnosis method can be attributed to many chief factors such as its variance in the gray zone, cutoff, and the recombinant antigens that using in complete virus assays.

\section{Conflict of Interest: None}

Funding: Self

Ethical Clearance: Not required

\section{References}

1. Walker PJ, Siddell SG, Lefkowitz EJ, et al. Changes to virus taxonomy and the International Code of Virus Classification and Nomenclature ratified by the International Committee on Taxonomy of Viruses. Arch Virol. 2019; 164(9):2417-2429.

2. Lambert N, Strebe $P$, Orenstein $W$, Icenogle J, and Gregory A. Lancet. 2015 June 6; 385(9984): 2297-
2307.

3. Lulandala L, Mirambo MM, Matovelo D, Gumodoka B, Mshana SE. Acute Rubella Virus Infection among Women with Spontaneous Abortion in Mwanza City, Tanzania. Journal of clinical and diagnostic research: JCDR. 2017;11(3):Qc25-qc7.

4. Dobson, S. R. Congenital Rubella Syndrome: Clinical Features and Diagnosis. 2014. Available at: http://www.uptodate.com/contents/congenitalrubella-syndrome clinical-featues-and-diagnosis.

5. Murhekar M, Bavdekar A, Benakappa A, Santhanam S, Singh K, Verma S. Sentinel Surveillance for Congenital Rubella Syndrome - India, 2016-2017. MMWR Morb Mortal Wkly Rep. 2018; 14;67(36):1012-6.

6. Boshoff L, Tooke L. Congenital rubella: is it nearly time to take action? South Afr J Child Health 2012; 6.

7. Mulders $\mathrm{M} \mathrm{N}$, Rota P A, Icenogle J P, Brown K E, Takeda M, Rey G J. Global measles and rubella laboratory network support for elimination goals, 2010-2015, Morbidity and Mortality Weekly Report. 2016; 65 (17) 438-442.

8. Hasan AS, Al-Duliami AA, Neima AA, and Al-Jurani AH. Seroppositivity of anti-rubella antibodies among premarriage girls in Diyala province. Diyala J for Pure Sience, 2011; 7(3) 259267.

9. Naqid IA, Yousif SH, Hussein NR. Seroprevalence of Rubella and Herpes Simplex Virus in Women with Miscarriage and Stillbirth in Zakho City, Kurdistan Region, Iraq: A Cross-Sectional Study. Women. Health. Bull. 2020; 7(1):18-22.

10. Mohammed RA, Kokaz MT. Rubella virus seroprevalence and associated factors in pregnant women with and without previous spontaneous abortion. Med J Babylon 2019;16:243-7.

11. Parlak M, Çim N, Nalça Erdin B, Güven A, Bayram Y, Yildizhan R. Seroprevalence of Toxoplasma, Rubella, and Cytomegalovirus among pregnant women in Van. Turk J Obstet Gynecol. 2015; 12(2):79- 82.

12. Seruyange E, Gahutu JB MD, Muvunyi C, PM, Katare S, Ndahindwa V, Sibomana $\mathrm{H}$, Nyamusore J, Rutagarama F, Hannoun C, Norder H, and Bergström T. Seroprevalence of Zika Virus and Rubella Virus IgG among blood donors in Rwanda and in Sweden. Journal of Medical Virology; 
DOI 10.1002/jmv.25090. International Journal of Medical Laboratory 2018; 5(3):173-181.

13. Dontigny L, Arsenault MY, Martel MJ.; CLINICAL PRACTICE OBSTETRICS COMMITTEE. Rubella in pregnancy. J Obstet Gynaecol Can 2008; 30 (02) 152-158.

14. Vauloup-Fellous $\mathrm{C}$ and Grangeot-Keros L. Humoral immune response after primary rubella virus infection and after vaccination. Clin Vaccine Immunol 2007; 14:644-7.

15. Best, J.M.; Cooray, S.; Banatvala, J.E. "45. Rubella". Topley and Wilson's Microbiology and Microbial Infections. 2 Virology. 2005; pp. 960992.

16. Coker RJ, Hunter BM, Rudge JW, et al. Emerging infectious diseases in Southeast Asia: regional challenges to control. Lancet. 2011; 377:599-609.
17. Caliendo AM, Gilbert DN, Ginocchio CC, et al. Better tests, better care: improved diagnostics for infectious diseases. Clin Infect Dis. 2013; 57:Suppl 3, S139-70.

18. Central Statistical Organization (CSO). Iraqi Ministry of Planning, 2018.

19. Mahmood TA, A. Sultan B, Mohammed SN and AL-Hucheimi SN. Serological and Molecular Diagnosis of Rubella virus and Cytomegalovirus in aborted Patients in Al-Najaf province. Kufa $\mathrm{J}$ for Nursing Sciences. 2015; 5 (2) 1-7.

20. Saadoon IH. Serodiagnosis of Rubella in Pregnant Women. Medical Journal of Babylon. 2016; 13(3): $628-634$.

21. Mohammed LM, Prevalence of rubella virus in pregnant women in Kirkuk city-Iraq. Kirkuk University Journal/Scientific Studies (KUJSS); 2015, 10 (1) 47-57. 